\author{
초음파를 이용한 한우 육량등급의 조기예측 \\ 이용준*석홍기**.김석중**.송영한** \\ 농촌진흥청 축산기술연구소*, 강원대학교 동물자원과학대학**
}

\title{
Early Prediction of Carcass Yield Grade by Ultrasound in Hanwoo
}

\author{
Y. J. Rhee*, H. K. Seok**, S. J. Kim** and Y. H. Song** \\ National Livestock Research Institute, RDA*, \\ College of Animal Resources Sciences, Kangwon National University**
}

\begin{abstract}
This study was carried out to make early prediction of carcass yield grade. Sixty six Hanwoo steers were measured for back fat thickness, longissimus muscle area and body weight at 18,21 and 24 months of age by ultrasound. Carcass evaluation was done after ultrasound measurement at 24 month of age. Ultrasonic yield grade at 18,21 and 24 month of age were predicted by regression and decision tree methods. Classifying by carcass yield grade, ultrasonic back fat thickness at 18, 21 and 24 months of age was significantly different in each carcass yield grade $(\mathrm{p}<0.05)$. The prediction accuracy of carcass yield grade by regression method was $78.8 \%$ at 18 months, $86.4 \%$ at 21 months and $90.9 \%$ at 24 months of age. By using the decision tree method for carcass yield grade, $78.8 \%, 89.4 \%$ and $89.4 \%$ of prediction accuracy were obtained at 18, 21 and 24 months of age, respectively.
\end{abstract}

(Key words : Ultrasound, Carcass traits, Early prediction, Hanwoo)

\begin{abstract}
I. 서 론
지금까지 육우의 산육성을 생체에서 추정하 는 기술에 관한 연구가 다각적인 측면에서 지 속적으로 수행되어져 왔으며, 특히 초음파 진 단장치를 이용하여 생체의 육질과 육량을 추정 하는 기술이 다양하게 응용되어지고 있다(Robinson 등, 1992; Song 등, 2002). 이 기술은 가축 에 무해하며 비교적 간단한 방법으로 살아있는 소의 산육능력을 평가할 수 있기 때문에 측정 당시의 성장 및 비육상태를 예측하여 출하시기 를 결정하는데 이용되고 있다. 또한, 증체능력

및 외관평가에 의해 선발하는 직접검정이나 송 아지의 자료를 이용할 수밖에 없는 번식암소의 선발에 있어서도 생체상태에서 그 당시의 산육 성 정보를 얻을 수 있기 때문에 초음파 진단기 를 육우의 육종에 활용하는 것이 가능하다(塬 田, 1994).

가축의 비육기간중 도체형질의 경시적 변화 를 명확히 구명하는 것은 비육기술향상에 큰 효과를 가져올 뿐만 아니라, 비육종료시 도체 형질의 조기추정도 가능하게 한다. 이미 초음 파를 이용하여 성장단계별 도체형질을 추정한 후 통계적 기법을 이용하여 비육종료시의 도체
\end{abstract}

본 연구는 한국학술진흥재단의 대학부설연구소 지원과제(KPF-99-005-G00011)로 수행된 연구결과임.

Corresponding author : Y. J. Rhee, Daekwanryeong Branch Station, National Livestock Research Institute, RDA, \#268, Chahang-ri, Doam-myeon, Phyongchang-gun, Gangwon-do, 232-952, Korea. Tel : 033)330-0631, Fax : 033)330-0660, E-mail : rheeyj@rda.go.kr 
실측치를 예측하는 연구가 다수 보고된 바 있 으나(䝠田, 1982, 1986; Haley 등, 1992; Hartjen 등, 1993; Gresham 등, 1994, Song 등, 2002), 한우에 대한 초음파를 이용한 도체형질의 조기 예측은 이제 시작단계에 있다. 소의 산육성은 품종, 성별 및 영양 등의 여러 요인에 영향을 받기 때문에 한우 도체형질의 조기예측을 위해 서는 우선적으로 성장단계에 따른 도체형질의 경시적 변화가 구명되어야 가능할 것으로 판단 된다.

본 시험은 초음파 진단기를 이용하여 한우의 성장단계에 따른 도체형질의 경시적 변화를 구 명하고, 각 성장단계별 초음파 추정치를 이용 하여 출하시의 도체육량을 예측하고자 실시하 였다.

\section{ㅍ. 재료 및 방법}

\section{1. 공시축 및 실험방법}

축산기술연구소 대관령지소의 제 30 차 후대 검정용 거세한우 66 두를 대상으로 생후 18,21 및 24 개월령에 체중측정과 함께 주파수 $2 \mathrm{MHz}$ 의 linear probe $(27 \times 147 \mathrm{~mm})$ 를 장착한 실시간 초 음파 진단기(Super-Eye Meat, FHK, Japan)를 이 용하여 제 13 흥추와 제 1 요추 사이의 횡단면을 측정하였고, 측정된 영상은 휴대용 $\mathrm{PC}$ 에 저장 한 후 계측 소프트 프로그램(Image-Pro Express, Media Cybernetics, USA)을 이용하여 배최장근 단면적과 등지방 두께를 측정하였다. 또한, 24 개월령 초음파 측정 후 1 주일 이내에 도축장으 로 이송하여 등급판정사에 의한 도체평가를 실 시하였다.

배최장근 단면적은 배최장근과 인근 조직 사 이 경계면의 반사파(echo)를 기준으로 배최장근 윤곽을 곡선으로 연결하여 측정하였고, 등지방 두께는 도체평가와 동일한 배최장근의 3 분의 2 지점에서 측정하였다.

\section{2. 조기 육량예 측 방법}

(1) 중회귀 분석
도체육량등급 평가에 이용되는 육량지수 산 식은 전형적인 1 차 선형식으로 회귀분석을 통 하여 초음파 측정치를 이용할 수 있는 새로운 공식을 유도할 수가 있다. 따라서 18, 21 및 24 개월령에 측정한 초음파측정 등지방 두께, 초 음파측정 배최장근 단면적 및 생체중을 독립변 수로 하고, 도체육량지수를 목적변수로 하여 SAS package(2000)를 이용한 중회귀 분석을 실 시하였다. 이 결과로부터 도출된 식에 초음파 측정 등지방 두께, 초음파측정 배최장근 단면 적 및 생체중을 대입하여 육량지수를 구하고, 육량지수가 69이상일 때에는 $\mathrm{A}$ 등급, 66이상 69 미만일 때에는 B등급, 그리고 66 미만일 때에는 $\mathrm{C}$ 등급으로 예측하였다.

$$
\begin{aligned}
& Y=\alpha+\beta_{1} x_{1}+\beta_{2} x_{2}+\beta_{3} x_{3} \\
& Y: \text { 도체육량지수 } \\
& \alpha: \text { 절편 } \\
& x_{1}: \text { 초믐파측정 등지방 두께 } \\
& x_{2}: \text { 초음파측정 배최장근 단면적 } \\
& x_{3}: \text { 생체중 } \\
& (\mathrm{A} \text { 등급 : } 69 \leq \mathrm{Y}, \mathrm{B} \text { 등급 }: 66 \leq \mathrm{Y}<69, \mathrm{C} \text { 등 } \\
& \text { 급 }: \mathrm{Y}<66)
\end{aligned}
$$

\section{(2) 의사결정나무 분석}

살아있는 한우의 초음파 측정시 측정환경, 소의 개체별 특성, 초음파 기계의 상태 등 여 러 요인에 의하여 등지방 두께와 배최장근 단 면적은 과대 또는 과소 추정될 수 있으며, 이 경우 중회귀 분석 모형에 상당한 영향을 미칠 수가 있다. 따라서 선형성의 가정을 필요로 하 지 않는 비모수적인 접근법과 두 개 이상의 변 수가 결합하여 목표변수에 어떠한 영향을 미치 는지 분석하는 교효효과의 분석방법이 필요하 다. 따라서 18,21 및 24 개월령에 측정한 초음 파측정 등지방 두께, 초음파측정 배최장근 단 면적 및 생체중을 입력변수로 하고 도체육량등 급을 목표변수로 하여 SAS Enterprise Miner 4.0(2000)을 이용한 decision tree 분석을 실시하 였다. 분석알고리즘은 CART 알고리즘을 이용 하였고, 각 변수에 대한 측도는 목표변수인 도 체육량 등급은 명목형, 입력변수인 등지방 두 
께, 배최장근 단면적 및 생체중은 각각 순서형, 연속형 및 연속형으로 설정하였으며, 부적절한 추론규칙을 가지고 있는 가지를 제거하고 최종 예측모형을 설정하였다.

\section{III. 결과 및 고찰}

1. 성장에 따른 초음파 측정치와 도체 실측 치의 비교

거세한우 66 두를 대상으로 18,21 및 24개월 령에 실시간 초음파 진단기를 이용한 도체형질 추정치와 24 개월령의 도체 실측치는 Table 1 에 나타낸 바와 같다. 월령에 따른 평균 체중은 각각 $446.6 \mathrm{~kg}, 507.9 \mathrm{~kg}$ 및 $563.9 \mathrm{~kg}$ 으로 직선적 인 성장패턴을 보였으며, 도체중은 $335.7 \mathrm{~kg}$ 으로 평균 $59.5 \%$ 의 도체율을 나타냈다. 등지방 두께 와 배최장근 단면적에서도 역시 월령이 경과함 에 따라 직선적인 패턴으로 증가하였으며, 24 개월령의 초음파 측정치와 도체 실측치간의 오 차는 등지방 두께와 배최장근 단면적에서 각각 $0.1 \mathrm{~mm}$ 및 $1.0 \mathrm{~cm}^{2}$ 를 보여 초음파에 의한 도체 형질의 예측 정확도가 높다는 것이 시사되었 다.

Table 2는 도체육량등급에 따라 개체를 A, $\mathrm{B}, \mathrm{C}$ 군으로 분류를 하고, 각 도체등급별로 월 령에 따른 도체형질의 변화를 나타내었다. 24 개월령 도체측정 결과, 총 66 두 중 도체육량 $\mathrm{A}, \mathrm{B}$ 및 $\mathrm{C}$ 등급이 각각 32 두, 29 두 및 5 두로
나타났다. 도체육량등급에 따른 개월별 체중은 $\mathrm{A}, \mathrm{B}, \mathrm{C}$ 등급 순으로 체중이 적은 경향을 보였 으며, 21 개월령과 24 개월령에서 $\mathrm{A}$ 등급이 $\mathrm{C}$ 등 급에 비하여 체중이 유의적 $(\mathrm{p}<0.05)$ 으로 적게 나타났다. 등지방 두께는 측정 전기간에 걸쳐 각 도체등급별로 유의적인 차이 $(\mathrm{p}<0.05)$ 를 보이 며, $\mathrm{A}, \mathrm{B}, \mathrm{C}$ 등급 순으로 얇은 것으로 나타났다. 배최장근 단면적은 전기간에 걸쳐 $\mathrm{A}, \mathrm{B}, \mathrm{C}$ 등급 순으로 큰 경향을 보였으나, 유의적인 차이를 보이지는 않았다.

도체시 적용되는 육량지수 산식을 보면 도체 육량등급의 결정에 등지방 두께, 배최장근 단 면적 및 도체중의 순으로 영향을 미치고, 이 중 등지방 두께가 가장 큰 영향을 미친다는 것 을 알 수 있다. 본 시험의 도체육량 등급에 따 른 도체형질을 비교한 결과에서 등지방 두께가 18 개월령부터 각 등급별로 유의적 $(\mathrm{p}<0.05)$ 인 차 이를 보임으로써 거세한우는 18 개월령부터 도 체육량의 조기 예측이 가능한 것으로 판단되었 다. 原田(1996)은 거세 흑모화우에 대한 도육형 질의 예측 기여율에 관한 연구에서 배최장근 단면적은 비육개시후 6 개월(생후 $15 \sim 16$ 개월 령)에서 $70 \%$ 이상의 예측 기여율을 나타내었 고, 피하지방두께는 비육개시후 $8 \sim 10$ 개월(생 후 17 20개월령)에서 $60 \%$ 이상의 예측 기여 율을 보여 비육종료후의 도체실측치를 충분히 예측할 수 있다고 보고하였다. 그러나 본 시험 에서는 초음파 측정시기를 18 개월령, 21 개월령, 24 개월령에 한정하였기 때문에 추후 초음파 측

Table 1. Means and those SD of carcass traits of Hanwoo steer estimated by ultrasonic and carcass measurements

\begin{tabular}{lcccc}
\hline \multirow{2}{*}{ Items } & \multicolumn{4}{c}{ Age (months) } \\
\cline { 2 - 5 } & 18 & 21 & 24 & 24 \\
\cline { 2 - 5 } & \multicolumn{4}{c}{ Carcass } \\
\cline { 2 - 5 } Body weight $(\mathrm{kg})$ & Ultrasound & & & - \\
\cline { 2 - 5 } Carcass weight $(\mathrm{kg})$ & $446.6 \pm 45.75^{\mathrm{c}}$ & $507.9 \pm 39.54^{\mathrm{b}}$ & $563.9 \pm 46.37^{\mathrm{a}}$ & - \\
$\mathrm{BFT}^{1)}(\mathrm{mm})$ & - & - & - & $335.7 \pm 30.41$ \\
$\mathrm{LMA}^{2)}\left(\mathrm{cm}^{2}\right)$ & $5.2 \pm 2.21^{\mathrm{c}}$ & $7.1 \pm 3.21^{\mathrm{b}}$ & $9.2 \pm 3.43^{\mathrm{a}}$ & $9.3 \pm 4.13^{\mathrm{a}}$ \\
\hline
\end{tabular}

\footnotetext{
1) Back Fat Thickness, ${ }^{2)}$ Longissimus Muscle Area.

a,b,c Means with different superscripts in the same row significantly differ $(p<0.05)$.
} 
Table 2. Means and those SD of carcass traits of Hanwoo steer classified by carcass yield grades

\begin{tabular}{lcccc}
\hline \multirow{2}{*}{ Items } & Age & \multicolumn{3}{c}{ Carcass yield grade } \\
\cline { 3 - 5 } & & $\mathrm{A}$ & $\mathrm{B}$ & $\mathrm{C}$ \\
\hline \hline \multirow{2}{*}{$\mathrm{BW}^{1)}$} & 18 & $441.5 \pm 40.74^{4) \mathrm{Cns}}$ & $442.3 \pm 52.64^{\mathrm{C}}$ & $478.4 \pm 14.15^{\mathrm{C}}$ \\
$(\mathrm{kg})$ & 21 & $497.0 \pm 36.90^{\mathrm{Bb}}$ & $515.1 \pm 42.14^{\mathrm{Bab}}$ & $535.2 \pm 12.07^{\mathrm{Ba}}$ \\
& 24 & $552.8 \pm 44.59^{\mathrm{Ab}}$ & $570.3 \pm 47.99^{\mathrm{Aab}}$ & $598.0 \pm 25.88^{\mathrm{Aa}}$ \\
\hline \multirow{2}{*}{$\mathrm{BFTU}^{2)}$} & 18 & $3.8 \pm 1.18^{\mathrm{Cc}}$ & $6.1 \pm 1.83^{\mathrm{Cb}}$ & $9.4 \pm 1.14^{\mathrm{Ba}}$ \\
$(\mathrm{mm})$ & 21 & $4.9 \pm 1.29^{\mathrm{Bc}}$ & $8.3 \pm 2.23^{\mathrm{Bb}}$ & $14.6 \pm 1.52^{\mathrm{Aa}}$ \\
\hline \multirow{2}{*}{$\mathrm{LMAU}^{3)}$} & 24 & $6.8 \pm 1.39^{\mathrm{Ac}}$ & $10.5 \pm 2.56^{\mathrm{Ab}}$ & $16.6 \pm 1.95^{\mathrm{Aa}}$ \\
$\left(\mathrm{cm}^{2}\right)$ & 18 & $63.4 \pm 6.32^{\mathrm{Cns}}$ & $61.9 \pm 6.31^{\mathrm{C}}$ & $59.9 \pm 7.40^{\mathrm{B}}$ \\
\hline
\end{tabular}

${ }^{1)}$ Body Weight, ${ }^{2)}$ Ultrasonic Back Fat Thickness, ${ }^{3)}$ Ultrasonic Longissimus Muscle Area,

4) Values represent means \pm S.D.

a,b,c Means with different superscripts in the same row significantly differ $(p<0.05)$.

${ }^{A, B, C}$ Means with different superscripts in the same column significantly differ $(\mathrm{p}<0.05)$.

${ }^{\text {ns }}$ Not significant in the same row.

Means \pm SD.

정시기를 비육 전기간을 대상으로 설정하여 측 정한다면 한우에 대한 정확한 조기 도체육량 예측시기를 구명할 수 있을 것으로 사료된다.

\section{2. 중회귀 분석을 이용한 조기 육량예측}

초음파를 이용한 조기 도체육량등급 예측을 위하여 18,21 및 24 개월령의 생체중, 초음파측 정 등지방 두께 및 배최장근 단면적을 입력변 수로 하고, 24개월령 도체육량지수를 목표변수 로 하여 중회귀 분석을 실시하였다.

18 개월령 초음파 측정치를 이용한 중회귀 분 석 결과 다음과 같은 공식이 도출되었다. 등지 방 두께는 $0.1 \%$ 하에서 유의성을 나타냈으며, 배최장근 단면적은 $1 \%$ 하에서 유의성이 있는 것으로 나타났다.

$$
\begin{aligned}
& \mathrm{Y}=68.53-0.00116 \times \mathrm{BW}(\mathrm{kg})-0.66503 \times \\
& \mathrm{BFU}(\mathrm{mm})^{* * *}+0.06264 \times \operatorname{LMAU}\left(\mathrm{cm}^{2}\right)^{* *} \\
& * * \mathrm{p}<0.01, * * * \mathrm{p}<0.001 .
\end{aligned}
$$

21 개월령 초음파 측정치를 이용한 중회귀 분 석 결과 다음과 같은 공식이 도출되었으며, 등
지방 두께와 배최장근 단면적에서 모두 유의성 $(\mathrm{p}<0.001)$ 이 있는 것으로 나타났다.

$$
\begin{aligned}
& \mathrm{Y}=68.21-0.00392 \times \mathrm{BW}(\mathrm{kg})-0.49014 \times \\
& \quad \mathrm{BFU}(\mathrm{mm})^{* * *}+0.08035 \times \operatorname{LMAU}\left(\mathrm{cm}^{2}\right)^{* * *} \\
& * * * \quad \mathrm{p}<0.001 .
\end{aligned}
$$

24개월령 초음파 측정치를 이용한 중회귀 분 석 결과 다음과 같은 공식이 도출되었다. 생체 중은 $5 \%$ 하에서 유의성이 인정되었고, 등지방 두께와 배최장근 단면적은 $0.1 \%$ 하에서 유의성 을 나타냈다.

$$
\begin{aligned}
& \mathrm{Y}= 69.04-0.00436 \times \mathrm{BW}(\mathrm{kg})^{*}-0.46029 \times \\
& \mathrm{BFU}(\mathrm{mm})^{* * *}+0.07595 \times \operatorname{LMAU}\left(\mathrm{cm}^{2}\right)^{* * *} \\
& * \mathrm{p}<0.05, * * * \mathrm{p}<0.001 .
\end{aligned}
$$

중회귀 분석에 의한 육량지수와 도체육량지 수간의 상관은 Table 3 에 나타낸 바와 같다. 18,21 및 24 개월령의 육량지수에서 각각 0.81 , 0.92 및 0.93 으로 모두 유의적 $(\mathrm{p}<0.001)$ 으로 높 은 상관을 나타냈다. 또한, 예측시기가 빠를수 
Table 3. Correlation coefficient between carcass yield grade index (YGIC) and ultrasonic yield grade index (YGIU) by the regression method

\begin{tabular}{cccc}
\hline \multirow{2}{*}{ Items } & \multicolumn{3}{c}{ YGIU by the regression method } \\
\cline { 2 - 4 } & 18 months & 21 months & 24 months \\
\hline \hline YGIC & $0.81^{* * *}$ & $0.92^{* * *}$ & $0.93^{* * *}$ \\
\hline$* * * \mathrm{p}<0.001$. & &
\end{tabular}

록 중회귀 분석에서 독립변수들의 유의성과 도 체육량지수와의 상관이 떨어지는 경향을 보였 으나, 모든 측정월령에서 조기예측이 충분한 것으로 나타났다.

중회귀 분석에 의한 육량지수를 이용하여 도 체육량등급을 예측한 결과를 Table 4에 나타냈 다. 18 개월령의 조기예측 결과, 도체육량 $\mathrm{A}$ 등 급에서 $78.1 \%, \mathrm{~B}$ 등급에서 $82.8 \%$, 그리고 $\mathrm{C}$ 등급 에서 $60.0 \%$ 로 전체 $78.8 \%$ 의 예측율을 나타냈 다. 21 개월령에 조기예측을 실시하였을 경우에 서는 $\mathrm{A}$ 등급이 $84.4 \%, \mathrm{~B}$ 등급이 $86.2 \%, \mathrm{C}$ 등급이 $100.0 \%$ 를 나타내어, 전체 예측율이 $86.4 \%$ 를 나 타냈다. 출하직전에 예측을 실시하였을 때에는 $\mathrm{A}$ 등급에서 $93.8 \%, \mathrm{~B}$ 등급에서 $86.2 \%, \mathrm{C}$ 등급에 서 $100.0 \%$ 로 전체 $90.9 \%$ 의 예측율을 나타냈다.
또한, 18 개월령 조기 예측에서는 출하직전에 실시한 예측율의 $86.7 \%$ 에 해당하는 예측율을 보였으며, 21 개월령에서는 $95.0 \%$ 에 해당하는 예측율을 나타냈다. 이 결과로 중회귀 분석을 이용한 거세한우의 조기 육량예측은 18 개월령 부터 가능한 것으로 판단되며, 추후 측정 공시 두수의 확보와 성장 전기간을 대상으로 초음파 측정이 이루어진다면 조기 예측시기를 앞당김 과 동시에 예측율 향상에도 기여할 수 있을 것 으로 사료된다.

\section{3. 의사결정나무 분석을 이용한 조기 육량예 측 \\ 초음파를 이용한 조기 도체육량등급 예측을}

Table 4. Prediction accuracy of carcass yield grade at 18, 21 and 24 months of age by the regression method

\begin{tabular}{|c|c|c|c|c|c|c|c|}
\hline \multirow{2}{*}{$\mathrm{YGC}^{1)}$} & \multirow{2}{*}{$\mathrm{YGU}^{2)}$} & \multicolumn{2}{|c|}{18 months of age } & \multicolumn{2}{|c|}{21 months of age } & \multicolumn{2}{|c|}{24 months of age } \\
\hline & & Heads & Accuracy & Heads & Accuracy & Heads & Accuracy \\
\hline \multirow{3}{*}{ A } & $\mathrm{A}$ & 25 & $78.1 \%$ & 27 & $84.4 \%$ & 30 & $93.8 \%$ \\
\hline & $\mathrm{B}$ & 7 & & 5 & & 2 & \\
\hline & $\mathrm{C}$ & 0 & & 0 & & 0 & \\
\hline \multirow[t]{2}{*}{ Subtotal } & & 32 & & 32 & & 32 & \\
\hline & A & 5 & & 3 & & 2 & \\
\hline \multirow[t]{2}{*}{$\mathrm{B}$} & $\mathrm{B}$ & 24 & $82.8 \%$ & 25 & $86.2 \%$ & 25 & $86.2 \%$ \\
\hline & $\mathrm{C}$ & 0 & & 1 & & 2 & \\
\hline \multirow[t]{2}{*}{ Subtotal } & & 29 & & 29 & & 29 & \\
\hline & $\mathrm{A}$ & 0 & & 0 & & 0 & \\
\hline \multirow[t]{2}{*}{$\mathrm{C}$} & B & 2 & & 0 & & 0 & \\
\hline & $\mathrm{C}$ & 3 & $60.0 \%$ & 5 & $100.0 \%$ & 5 & $100.0 \%$ \\
\hline Subtotal & & 5 & & 5 & & 5 & \\
\hline Total & & 66 & $78.8 \%$ & 66 & $86.4 \%$ & 66 & $90.9 \%$ \\
\hline
\end{tabular}

1) Carcass Yield Grade, ${ }^{2)}$ Ultrasonic Yield Grade. 
위하여 18,21 및 24 개월령의 초음파측정 등지 방 두께, 초음파측정 배최장근 단면적 및 생체 중을 입력변수로 하고, 24 개월령 도체육량등급 을 목표변수로 하여 의사결정나무 분석을 실시 하였다. 그 결과로 도출된 도체육량등급의 분 류도를 Fig. 1, Fig. 2 및 Fig. 3에 나타냈다. 18 개월령에서는 등지방 두께가 $3 \mathrm{~mm}$ 이하이고 배
최장근 단면적이 $48.3 \mathrm{~cm}^{2}$ 이상인 개체와 등지 방 두께가 $4 \mathrm{~mm}$ 이면서 배최장근 단면적이 63.3 $\mathrm{cm}^{2}$ 이상인 개체는 $\mathrm{A}$ 등급으로 예측하였고, 등지 방 두께가 $10 \mathrm{~mm}$ 이상인 개체는 $\mathrm{C}$ 등급으로 예 측하였으며, 나머지는 모두 $\mathrm{B}$ 등급으로 예측하 였다. 21개월령에서는 등지방 두께가 $6 \mathrm{~mm}$ 이하 이면서 배최장근 단면적이 $70.5 \mathrm{~cm}^{2}$ 이상인 개체

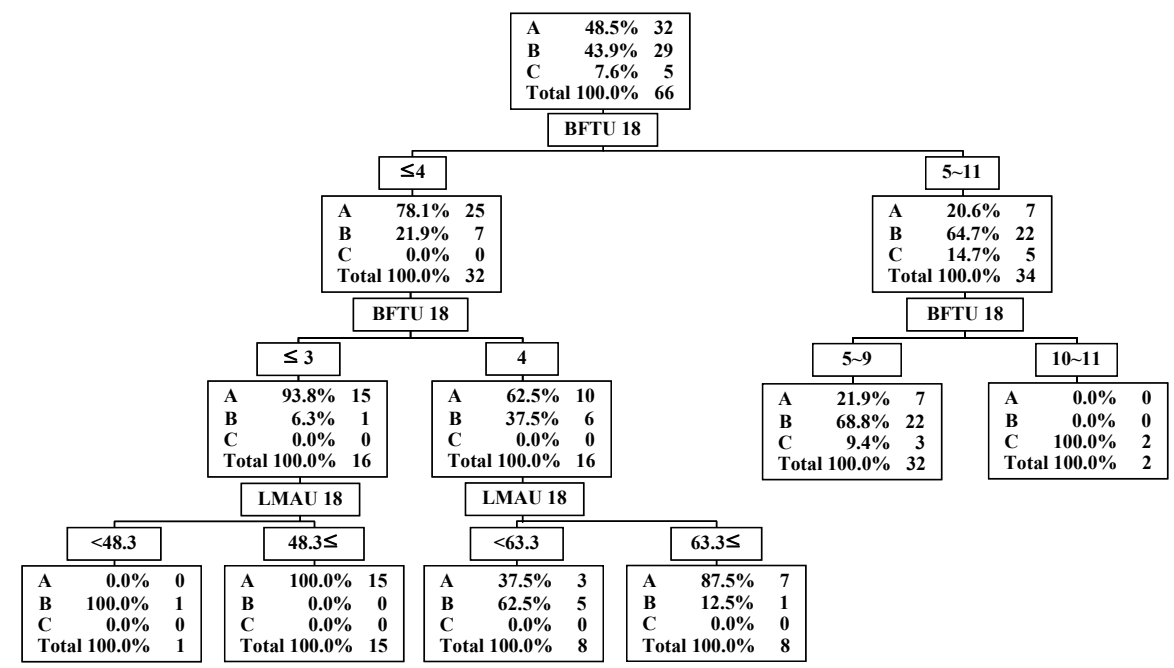

Fig. 1. Distribution pattern of carcass yield grade at 18 months of age by the decision tree method.

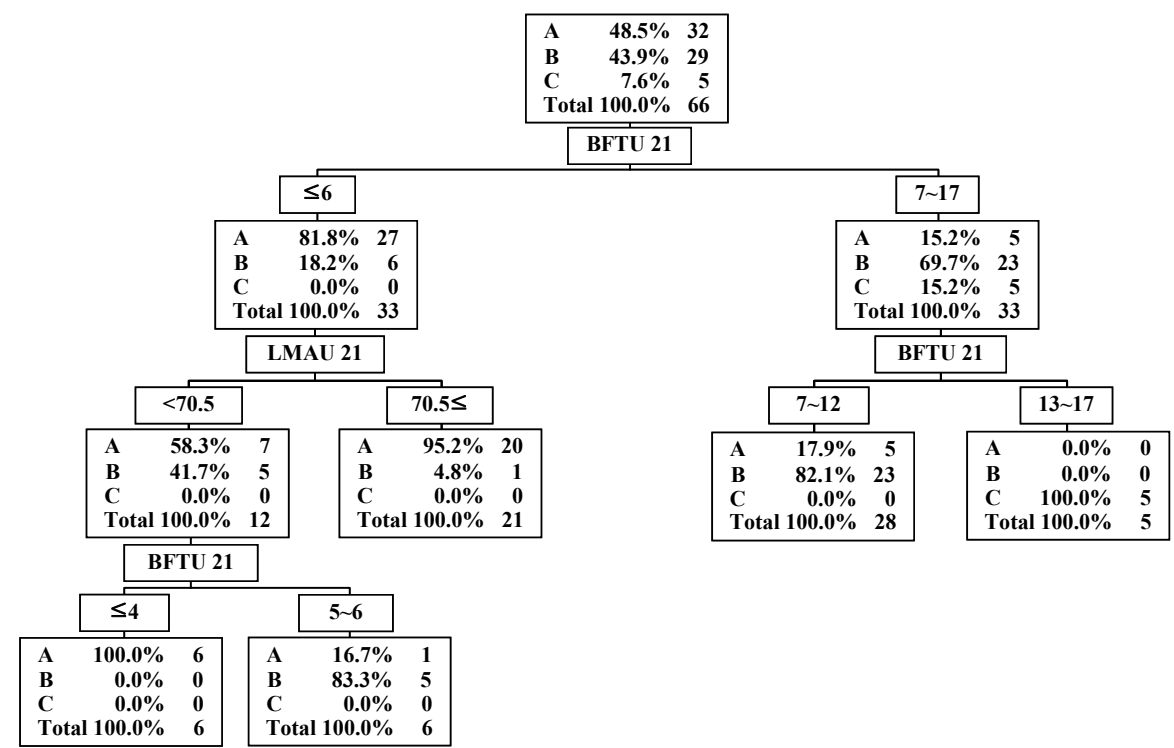

Fig. 2. Distribution pattern of carcass yield grade at 21 months of age by the decision tree method. 


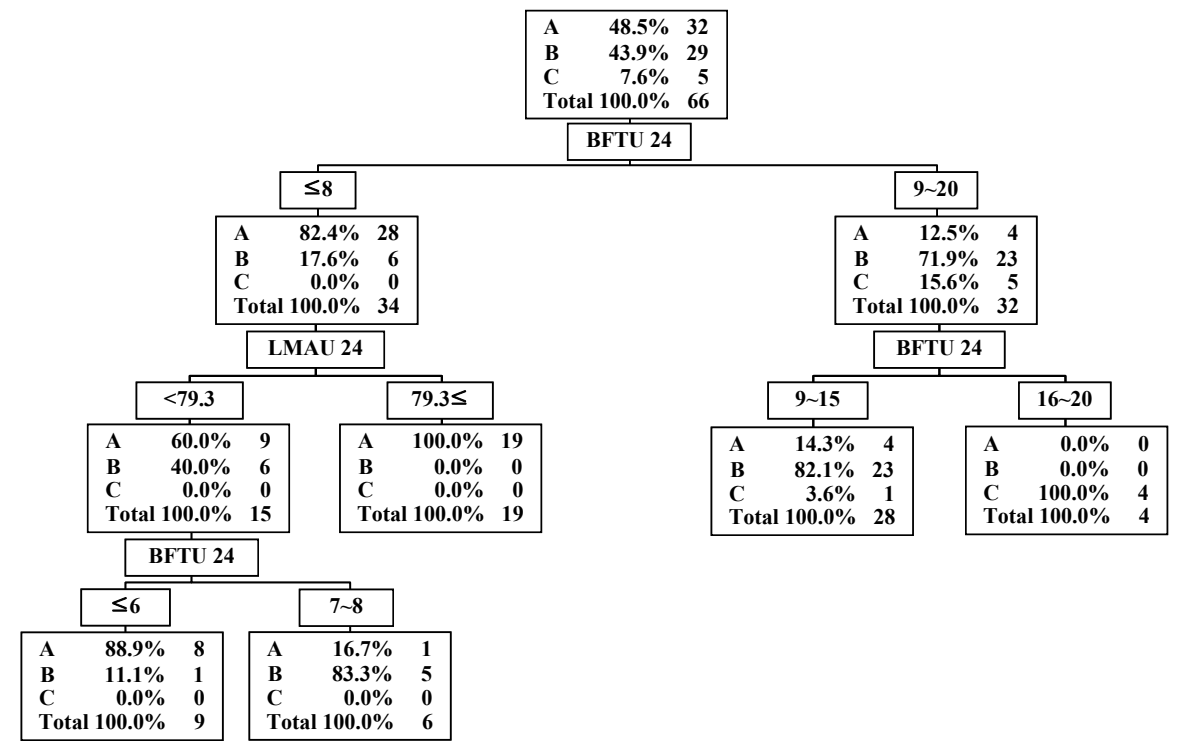

Fig. 3. Distribution pattern of carcass yield grade at 24 months of age by the decision tree method.

Table 5. Prediction accuracy of carcass yield grade at 18,21 and 24 months of age by the decision tree method

\begin{tabular}{|c|c|c|c|c|c|c|c|}
\hline \multirow{2}{*}{$\mathrm{YGC}^{1)}$} & \multirow{2}{*}{$\mathrm{YGU}^{2)}$} & \multicolumn{2}{|c|}{18 months of age } & \multicolumn{2}{|c|}{21 months of age } & \multicolumn{2}{|c|}{24 months of age } \\
\hline & & Heads & Accuracy & Heads & Accuracy & Heads & Accuracy \\
\hline \multirow{3}{*}{ A } & $\mathrm{A}$ & 22 & $68.8 \%$ & 26 & $81.3 \%$ & 27 & $84.4 \%$ \\
\hline & $\mathrm{B}$ & 10 & & 6 & & 5 & \\
\hline & $\mathrm{C}$ & 0 & & 0 & & 0 & \\
\hline \multirow[t]{2}{*}{ Subtotal } & & 32 & & 32 & & 32 & \\
\hline & $\mathrm{A}$ & 1 & & 1 & & 1 & \\
\hline \multirow[t]{2}{*}{$\mathrm{B}$} & $\mathrm{B}$ & 28 & $96.6 \%$ & 28 & $96.6 \%$ & 28 & $96.6 \%$ \\
\hline & $\mathrm{C}$ & 0 & & 0 & & 0 & \\
\hline \multirow[t]{2}{*}{ Subtotal } & & 29 & & 29 & & 29 & \\
\hline & $\mathrm{A}$ & 0 & & 0 & & 0 & \\
\hline \multirow[t]{2}{*}{$\mathrm{C}$} & $\mathrm{B}$ & 3 & & 0 & & 1 & \\
\hline & $\mathrm{C}$ & 2 & $40.0 \%$ & 5 & $100.0 \%$ & 4 & $80.0 \%$ \\
\hline Subtotal & & 5 & & 5 & & 5 & \\
\hline Total & & 66 & $78.8 \%$ & 66 & $89.4 \%$ & 66 & $89.4 \%$ \\
\hline
\end{tabular}

1) Carcass Yield Grade, ${ }^{2)}$ Ultrasonic Yield Grade.

와 배최장근 단면적이 $70.5 \mathrm{~cm}^{2}$ 미만이면서 등지 등지방 두께가 $8 \mathrm{~mm}$ 이하이면서 배최장근 단면 방 두께가 $4 \mathrm{~mm}$ 이하인 개체는 $\mathrm{A}$ 등급으로 예측 하였고, 등지방 두께가 $13 \mathrm{~mm}$ 이상인 개체는 $\mathrm{C}$ 적이 $79.3 \mathrm{~cm}^{2}$ 이상인 개체와 배최장근 단면적이 $79.3 \mathrm{~cm}^{2}$ 미만이면서 등지방 두께가 $6 \mathrm{~mm}$ 이하인 등급으로 예측하였으며, 나머지는 모두 $\mathrm{B}$ 등급 개체는 $\mathrm{A}$ 등급으로 예측하였고, 등지방 두께가 으로 예측하였다. 또한, 출하직전의 예측에서는 $16 \mathrm{~mm}$ 이상인 개체는 $\mathrm{C}$ 등급으로 예측하였으며, 
나머지 개체는 모두 $\mathrm{B}$ 등급으로 분류를 하였다.

의사결정나무 분석에 의한 18,21 및 24 개월 령의 도체육량등급 예측율은 Table 5에 나타낸 바와 같다. 18 개월령에 조기 예측을 실시한 결 과, 도체육량 $\mathrm{A}, \mathrm{B}$ 및 $\mathrm{C}$ 등급에서 각각 $68.8 \%$, $96.6 \%$ 및 $40.0 \%$ 의 예측율을 보였고, 전체 예측 율은 $78.8 \%$ 로 중회귀 분석과 동일한 것으로 나 타났다. 21 개월령에 도체육량등급의 예측을 실 시한 결과에서는 $\mathrm{A}$ 등급이 $81.3 \%, \mathrm{~B}$ 등급이 96.6 $\%, \mathrm{C}$ 등급이 $100.0 \%$ 로 전체 $89.4 \%$ 의 예측율을 보였고, 중회귀 분석에 의한 예측율 보다 $3 \%$ 향상된 결과를 나타냈다. 출하직전의 예측에서 는 $\mathrm{A}$ 등급이 $84.4 \%, \mathrm{~B}$ 등급이 $96.6 \%$, 그리고 $\mathrm{C}$ 등급이 $80.0 \%$ 로 전체 $89.4 \%$ 의 예측율을 나타 냈다. 의사결정나무 분석을 이용한 조기 육량 예측을 실시한 결과, 18 개월령에서 출하직전에 실시한 예측율의 $88.1 \%$ 에 해당하는 예측율을 나타냈고, 21 개월령에서는 출하직전의 예측율 과 동일한 결과를 나타냈다.

이상의 결과로 볼 때, 중회귀 분석과 의사결 정나무 분석에 의해 출하 3 개월 및 6 개월전에 도체육량등급을 예측한 결과, 두 방법 모두에 서 높은 예측율을 나타내어 초음파를 이용한 거세한우의 조기 육량예측이 가능한 것으로 판 명되었으며, 특히 의사결정나무 분석에 의한 조기 예측은 우형기가 설치되어있지 못한 일반 농가를 대상으로 그 이용가능성이 매우 높을 것으로 사료된다.

\section{IV. 요 약}

본 시험은 초음파를 이용하여 한우의 도체형 질을 조기에 예측하기 위하여 거세한우 66 두를 대상으로 18,21 및 24 개월령에 도체형질을 측 정하고, 중회귀 분석 및 의사결정나무 분석을 이용하여 24개월령 출하시 도체형질을 예측하 였다. 그 결과를 요약하면 다음과 같다. 도체육 량등급에 따라 군을 분류하고 성장에 따른 도 체형질의 변화를 관찰한 결과, 등지방 두께는 전기간에 걸쳐 각 도체육량등급간에 유의적 $(\mathrm{p}<0.05)$ 인 차이를 보이며 $\mathrm{A}, \mathrm{B}, \mathrm{C}$ 등급 순으로 얇게 나타났다. 중회귀 분석에 의한 도체육량 등급의 예측율은 18,21 및 24 개월령에서 각각
$78.8 \%, 86.4 \%$ 및 $90.9 \%$ 를 나타냈으며, 의사결정 나무 분석에 의한 도체육량등급 예측율은 각 개 월령에 따라 $78.8 \%, 89.4 \%$ 및 $89.4 \%$ 를 나타냈다.

\section{$\mathrm{V}$. 인 용 문 헌}

1. Gresham, J. D., McPeake, S. R., Bernard, J. K., Riemann, M. J., Wyatt, R. W. and Henderson, H. H. 1994. Prediction of live and carcass characteristics of market hogs by use of a single longitudinal ultrasonic scan. J. Anim. Sci. 72: 1409-1416.

2. Haley, C. S., Dagaro, E. and Ellis, M. 1992. Genetic components of growth and ultrasonic fat depth traits in meishan and large white pigs and their reciprocal crosses. Anim. Prod. 54:105-115.

3. Hartjen, P., Preisinger, R. and Ernst, E. 1993. Prediction of bovine carcass composition. 1. Prediction of carcass composition of live cattle using ultrasonic measurements and at carcass side using additional traits. Arch. Tierzucht. 36:315- 324.

4. Robinson, D. L., McDonaId, C. A., Hammond, K. and Turner, J. W. 1992. Live animal measurement of carcass traits by ultrasound assessment, accuracy of sonographers. J. Anim. Sci. 70:16671676.

5. SAS. 2000. Getting Started with the Enterprise Miner Software. Release 4.1. SAS Institute Inc. Cary. NC. USA.

6. SAS. 2000. SAS/STAT User's Guide. Version 8. SAS Institute Inc. Cary. NC. USA.

7. Song, Y. H., Kim, S. J. and Lee, S. K. 2002. Evaluation of ultrasound for prediction of carcass meat yield and meat quality in korean native cattle (Hanwoo). Asian-Aust. J. Anim. Sci. vol. 15. 4:591-595.

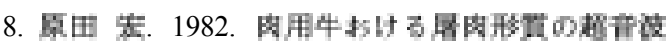

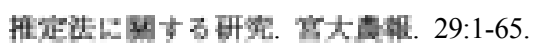

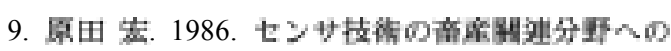

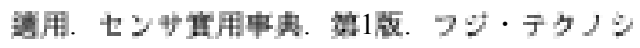
ステム、東京. pp. 978-1002.

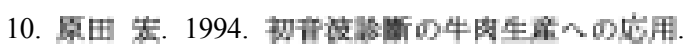
落度の开究. 48(1):170-176.

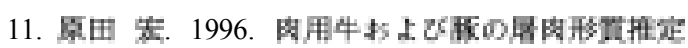

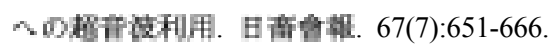

(접수일자 : 2002. 12. 6 / 채택일자 : 2003. 2. 12) 